\title{
Independence and Responsibility of the Students Through Online Learning
}

\author{
Yuni Sudiasih $^{1}$, Trisnaningsih ${ }^{2}$, Risma Margaretha Sinaga $^{3}$ \\ \{yuni@sman1tumijajar.sch.id ${ }^{1}$, trisna_unila@yahoo.co.id ${ }^{2}$, sinaga_margaretha@yahoo.com ${ }^{3}$ \} \\ Lampung University, Bandar Lampung, Indonesia ${ }^{1,2,3}$
}

\begin{abstract}
Building character was the educational function that must be achieved through the learning process both offline and online. Cooperation and good communication were needed between students, teachers and parents to overcome the kinds of obstacles. The competent teachers in providing learning experiences and methods were needed to make students enjoy learning. Parents' companionship and support were expected to have an impact on the development of independent and responsible character for their children. Various efforts in building independence and responsibility of students in online learning had answered in qualitative research conducted at SMAN 1 Tumijajar. The data was obtained by distributing questionnaires to parents, students and teachers through the WhatsApp group. Online interviews were conducted with students. The result showed that students' independence and responsibility had been developed trough the online learning.
\end{abstract}

Keywords: independence, responsibility, online learning.

\section{Introduction}

National education had the function to develop abilities and the dignified character and civilization of the nation in order to educate the life of the nation, purposed to develop the potential students to become human beings who believe and fear the One True God, noble, healthy, friendly, capable, creative, independent, and become democratic and responsible citizens [1]. The learning process in any situation was not only prioritized to achieve curriculum targets, but had to prioritize the character building.

Parents involvements were needed in the learning process, especially in terms of character building. Hatimah quoted Lilawati said that education was not only the government reponsibility, but also the school (teachers), and families (parents) [2]. Parents were the first guide in basic attitudes and skills, such as religious education to obey the rules, and for good habituation. But, in online learning role was increasingly. Parents had to accompany their children to learn at home. Therefore, collaboration between teachers and parents were needed to overcome various obstacles.

From the results of pre survey at several high schools in Tulang Bawang Barat Regency obtained, researcher got the information about the obstacles faced in online learning. They were technical and substantive constraints. The technical constraints included: 1) Several students didn't have learning devices such as laptops, tablets, or androids; 2) the internet network had not been evenly distributed well; 3) the unstable internet connection; and 4) not all parents were able to provide data package for their children. Substantive constraints included 1) ICT competence of teachers; 2) limited ability of teachers to manage innovative learning in online 
learning; 3) motivation of students to follow online learning; and 4) support and involvement from the parents in online learning activities conducted by their children.

The students had to change the interaction pattern with their friend. They had to use phone or android to make a good relation without meeting others. They had to learn without teacher and friends beside them. It was difficult but they had to. The assignment gave by the teacher had to done. They felt boring and reluctance to follow online learning. The independence and responsibility of students in participating the online learning had to be built as the main character. As Lickona said that characters didn't just appear, but process from continuously constructed environments simultaneously [3].

To create a good online learning, teachers needed to improve paedagogic and ICT. Mastery of ICT was a part of the teacher competence. It used to support the implementation of teachers duties (planning, presentation of learning, evaluation and analysis of evaluation results). So that every teacher at all levels had to be ready to continue learning ICT in order to meet the demands of such competencies [4]. Teachers should be able to create effective communication in the online class. Teachers established communication and collaboration with parents. Parental involvement in online learning activities was urgently needed with regard to the process of monitoring and building character values, especially independence and responsibility.

The value of self-character was attitudes and behaviors that didn't depend on others and used all energy, mind, time to realize hopes, dreams, and ideals [5]. Independent children had a good work ethic, resilient, fighting, professional, creative, courageous, and became longlife learners [6].

Responsibility was an embodiment of one's integrity. Responsibility was described as the attitude and behavior of a person to carry out his duties and obligations, which he should do, towards himself, society, environment (nature, social and cultural), the country and the God [5]. In home learning activities, the establishment of an attitude of responsibility to the child began by building the child's awareness that they had to be responsible in every way including when giving home chores, they had to do so [5].

Various efforts to build students' independence and responsibility in online learning had been answered in qualitative research held at SMAN 1 Tumijajar.

\section{Method}

This research used qualitative methods that aim to describe the online learning process in building the values of independence and responsibility of students.

The subjects were students of Grade XI IPS 3 and XI IPS 4 SMAN 1 Tumijajar who participated in the online learning at the first semester year of study 2020/2021. Consisted of 66 students, 26 persons (39.39\%) male and 40 female (60.61\%). Data collection was conducted by questionnaire and interview method of 5 informants who stated willingness to be interviewed online using WhatsApp video calls and offline through face-to-face meetings with researchers. The reason for choosing 5 informants was they were willing to disclose the online learning process that had been followed.

Analysis of research data used the Miles \& Huberman analysis model. The stages in the data analysis according to Miles \& Huberman quoted by Albi Anggito and Johan Setiawan (2018) consisted of data reduction, data display, withdrawal and verification of conclusions [7]. 

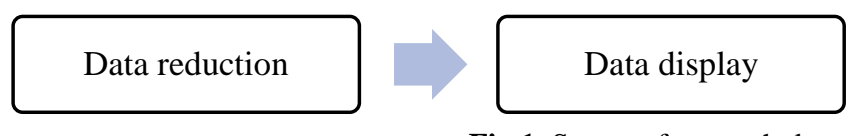

Fig 1. Stages of research data analysis
Decision making \& verificarion

The data reduction stage was the stage of collecting all the information needed from the interview results and then grouping the data. The data display stage was the exposure of data required in research and that does not need to be discarded. The verification and conclussion were the stage of interpretation of research data to take conclusions based on the phenomenon obtained [7].

\section{Results and Discussions}

\subsection{Online Learning Process}

Based on the results of online questionnaires spread using online classes and WhatsApp group classes with 66 respondents students obtained information about the type of online classes used in online learning in class XI IPS 3 and XI IPS 4 found at the following table:

Table 1. Types of online classes used.

\begin{tabular}{lccc}
\hline \multirow{2}{*}{ Subject } & \multicolumn{3}{c}{ Type of online classes } \\
\cline { 2 - 4 } & Google Classroom & WhatsApp Group & Microsoft Kaizala \\
\hline Religious & $\mathrm{v}$ & $\mathrm{v}$ \\
Education & & $\mathrm{v}$ \\
Civic Education & $\mathrm{v}$ & $\mathrm{v}$ \\
Indonesia & $\mathrm{v}$ & \\
English & $\mathrm{v}$ & \\
Phisical education & & $\mathrm{v}$ \\
\& health sciences & & $\mathrm{v}$ \\
Indonesian History & $\mathrm{v}$ & \\
Art \& Culture & $\mathrm{v}$ & \\
Mathematic & $\mathrm{v}$ & $\mathrm{v}$ \\
Economy & $\mathrm{v}$ & $\mathrm{v}$ \\
Geography & $\mathrm{v}$ & \\
History & $\mathrm{v}$ & \\
Sociology & & $\mathrm{v}$ \\
Craft & $\mathrm{v}$ & \\
Local Language of & $\mathrm{v}$ & $\mathrm{v}$ \\
Lampung & & $\mathrm{v}$ \\
English literature & & \\
\hline
\end{tabular}

Based on table 1, we could say that the process of online learning in class XI IPS 3 and XI IPS 4 SMAN 1 Tumijajar, 93.33\% used assynchronous method. The lesson of Penjasorkes didn't do online learning. Teacher asked the students to take exercises at home. The assynchronous method was considered the easiest and didn't require a large of data package. The school management didn't require used of certain methods in online learning. But teachers should be able to create the learning without burdening students. 
Online classes used by teachers according to students could add insight and experience to online learning. It through the online classes that students perform a variety of learning activities that desperately needed support from parents.

Table 2. Parental support in online learning.

\begin{tabular}{lcc}
\hline \multicolumn{1}{c}{ Kinds of constraint } & $\begin{array}{c}\text { Number of } \\
\text { respondent }\end{array}$ & Percentage \\
\hline Buying the data package as needed & 38 persons & 57,57 \\
Providing wi-fi & 5 persons & 7,58 \\
Askingquestions about the child's development in & 6 persons & 9,09 \\
taking online learning & & \\
Reminind children to take online lessons & 14 persons & 21,21 \\
Helping to overcome learning difficulties & 3 persons & 4,55 \\
\hline
\end{tabular}

Most of parents supported the implementation of online learning. Parents did many ways to support their child in online learning. Most parents $(56 \%)$ were willing to buy data package according to the needs of the child and provided wi-fi (5\%). Asking about children's learning development during online learning (14\%). Reminding children followed online learning at learning hours $(20 \%)$ and helped children overcame learning difficulties $(5 \%)$.

Through good communication between teachers and parents, it was expected that parents would be able to solve online learning problems faced by children. Communication and interaction between students and teachers certainly were not as effective as the communication beyween parents and their children (students).

Communication patterns between students and teachers or inter-students were limited. Communication conducted between students or between teachers and students were limited to provide motivation in learning and discussed of various phenomena or issues about difficulties in online learning. Exposing the subject matter also occured indirectly which can be made easier by the proper use of learning media. Fostering a responsible and independent character were the very essence things to practice in online learning.

Based on the results of online questionnaires spread using online classes and WhatsApp group classes with 66 respondents, researcher got the information about various obstacles encountered in online learning in the class of XI IPS 3 and XI IPS 4, found at the following table:

Table 3. Technical constraints in online learning.

\begin{tabular}{lcc}
\hline \multicolumn{1}{c}{ Kinds of constraint } & $\begin{array}{c}\text { Number of } \\
\text { respondent }\end{array}$ & Percentage \\
\hline Network disruption & 56 persons & 85 \\
Out of data package & 10 persons & 15 \\
\hline
\end{tabular}

The constraints found in online learning consisted of technical and substantive. Technical constraints encountered by students in following online learning in the form of network disruptions. It this was experienced by 56 students (85\%). $30 \%$ of students complained about the data package. $15 \%$ respondents thought that the unavailable data package was the main obstacle. The unavailable data package related to the high price of quota and the low economic capabilities of parents so that they could not afford data packages. 
This substantive obstacle related to students' motivation in participating in online learning. Some of the students interviewed expressed boredom with the implementation of online learning. It was because online classroom management hadn't be maximal and needed to be improved. The competence of ICT teachers, the ability to design innovative learning, the ability to create or provide media and teaching materials had to be always improved. Teachers individually and by groups in official organizations should be able to make various breakthroughs to improve those competencies. The school as an institution through that the programs had conducted teacher trainings to improve the quality of learning itself. The government actually often facilitates teacher training activities with the same purpose. Unfortunately, these facilities hadn't been utilized best. Some of the teacher only taook the training activities to get certificates, not knowledge and experience.

To make students felt enjoying and motivated to take the online classes, teachers had to skilled in managing online classes. To create online classes, the school had conducted In House Training activities at the beginning of the 2020/2021 school year. Teachers were guided to select and created online classes such as Goggle Classroom, WhatsApp Group, and Microsoft Kaizala. Another activity that teachers had done before starting online learning were managing online classes. In managing online classes, teachers were required to provide teaching materials or learning media in both file and link form. It meant that the provision of media and teaching materials hadn't to create by themselves. Teachers could pick it up from media and teaching materials from the web. If the teacher took media or teaching materials from the web, they had to written down the source of the material had been taken. The teaching materials inputted into the online class were certainly very varied. Starting from files in the form of documents, pdf, images, videos, interactive media, or links. Providing varied teaching materials could added insight and experiences of the students in following online learning.

After setting up the class, the thing had to be done was input the student into the class or providing code for them joining the class. After it, teacher posted materials, assignments, or questions to be discussed by the the students. By posting the materials, teachers could see the depth of students' way of thinking in responsed to a problem. Teachers with students then discussed it as they done in the real class. One of the advantages of online classroom discussion was that students were sure to express their opinions.

Material submitted in online classes ofcourse could be downloaded by students. So, they could learn it without connected to the internet. In online classes, teachers also gave assignments. Students were given flexibility ways to submit the task. If the students got some trouble in submitting task, they were permitted to do it offline. For example by writing the results of a student's work report in the book. Then they sent it to the teacher.

Table 4. Student learning activities in online classes.

\begin{tabular}{lcc}
\hline \multicolumn{1}{c}{ Kinds of activities } & $\begin{array}{c}\text { Number of } \\
\text { respondent }\end{array}$ & Percentage \\
\hline Doing attendance & 27 persons & 40,91 \\
Doing task & 21 persons & 31,81 \\
Learning material & 9 persons & 13,64 \\
Disscusion & 9 persons & 13,64 \\
\hline
\end{tabular}

Filling in attendance was the most activity had done by students. 27 Students $(40.91 \%)$ said that they prioritized attendance during other learning activities. 21 Students $(31.81 \%)$ choose to do assignments in online class. 9 persons $(13,64 \%)$ learnt material and discussed a particular topic were the order activity said by others. The spread of this data showed 
ineffectiveness of online learning. Therefore, teachers needed to improve their competence in managing online classes.

Attendance list was provided by curriculum section. for all students and classes. Students had to fill out forms distributed in online classes. It was done to control online learning process as well as to ensure that students remain facilitated to learn.

We also found that there was a tendency for students not to follow online learning even though they didn't actually have any obstacles. Actually, they didn't have any problem with the internet network or unavailable internet quota. But they said that they were in trouble. It was actually just a reason given to the teaacher. They kept doing activities online, such as played online games, enjoyed their social media (facebook, instagram, line, etc.), accessed youtube, and played tick-toks. As for downloading learning apps, they gave reason that their android memory was not enough. In fact, this could be done by removing other applications less useful to students. But they were reluctant to do it.

It became a challenge for a teacher to be able in managing online classes. Creativity and innovative had been developed. Paedagogic and ICT competencies balanced. Teachers were also required to be able to establish good communication and emotional bonds with students and parents.

\subsection{Building independence Character Through The Online Learning}

The values of self-character had to be grown through offline and online learning. Asmani (2011) quoted by Purandina (2020) argued that the purpose of independent character education was built the values of independence in students and the renewal of a common living system that better respects individual freedom. Hasan (Zubaedi, 2011:18) was quoted by Purandina (2020) said that independent character education in detail had five objectives. First, developing the potential of conscience/ affective students as human beings and citizens who had the values of the character of the nation [7]. Second, developing commendable habits and behaviors in line with universal values and cultural traditions of a nation that had the right to govern itself with the aim of maintaining public order. Third, building spirit of leadership and responsibility of learners as the next generation of the nation. Fourth, developing the skills into responsible, creative, and nationally minded human beings. Fifth, developing school environment life as a safe, honest learning environment, full of creativity and friendship, and with a high sense of nationality and dignity.

Table 5. Completion of assignments / materials in online learning.

\begin{tabular}{lcc}
\hline \multicolumn{1}{c}{ Kinds of activities } & $\begin{array}{c}\text { Number of } \\
\text { respondent }\end{array}$ & Percentage \\
\hline Studying assigments or materials by themselves & 57 persons & 86,36 \\
Asking help from parents or family & 6 persons & 9,09 \\
Leaving material in the online class & 3 persons & 4,55 \\
\hline
\end{tabular}

From the results of the questionnaire filled out using Microsoft Forms, 57 respondents $(86.36 \%)$ said that they had studied material themselves without help from others, both parents and families. 6 respondents $(9.09 \%)$ asked parents and siblings helping them to understand the material presented by the teacher. 3 respondents $(4.55 \%)$ said that they only allowed material in the online class. The way that students learnt materials independently by downloading the material. 
Students' independence in the implementation of online learning could also be seen from the enthusiasm of students to complete the task given by the teacher. The majority of students are about 57 respondents $(86.36 \%)$ completed the task alone without help from parents, relatives or friends. Some respondents in interviews conducted online admitted that they only cheated on a friend's completed assignment. It was caused the other student uploaded the tasks in online classes. To anticipate it, teacher asked them to send the task individually to the teacher.

\subsection{Building The Character of Responsibility Through Online Learning}

Based on the results of online questionnaires spread using online classes and WhatsApp group class with 66 students respondents, 51 persons had attanding in class to follow the online learning. Others got problems to attend the class caused of some reasons. 42 repondents said that they got connection trouble, 16 respondents caused of the data package was run out, 3 respondents worked for helping parents, others gave no reason and forgot it.

Table 6. Reasons of student's absence.

\begin{tabular}{lcc}
\hline \multicolumn{1}{c}{ Kinds of reasons } & $\begin{array}{c}\text { Number of } \\
\text { respondent }\end{array}$ & Percentage \\
\hline Network disruption & 42 persons & 63,64 \\
Out of data package & 16 persons & 22,24 \\
Worked to help parents & 3 persons & 4,54 \\
Forgot to learn & 1 person & 1,52 \\
Gave no reason & 2 persons & 6,06 \\
\hline
\end{tabular}

With the presence of students in online classes, it interpreted that students had responsibility in joining the online learning. It based on the reason for the student's absence and how they did some efforts to replace his absence in the online class.

One of the points used to see students' presence in online classes was from presence list shared by whatsApp group. Student absence was not a sign that they were not responsible. Students who fill in the attendance list couldn't be said that they were responsible. It caused they had saved the attendance list link had been created by the curriculum team.

Most teachers used attendance provided by the curriculum team. Some students admitted that they had kept attendance list link. Therefore, the attendance list in online classes couldn't be used as a measure for the responsible character.

Table 7. Students' activities when they weren't in the class.

\begin{tabular}{lcc}
\hline \multicolumn{1}{c}{ Kinds of activities } & $\begin{array}{c}\text { Number of } \\
\text { respondent }\end{array}$ & Percentage \\
\hline Contact the teacher to ask for additional time & 37 persons & 56,06 \\
Complete the task offline & 15 persons & 22,73 \\
Complete the task as they could & 12 persons & 18,18 \\
Gave no excuses & 2 persons & 3,03 \\
\hline
\end{tabular}

Timely assignment sharing was key indicator used to measure students' responsibility for learning in online classes. If a student had not completed their assignment in time, 37 respondents $(56.06 \%)$ asked the teacher giving them additional time. 15 respondents $(22.73 \%)$ had choosen to complete the task offline, 12 respondents $(18.18 \%)$ complete the task as they 
could, and 2 respondents $(3.03 \%)$ didn't not give a reason for the efforts to be made at the time of not completing the task.

In online class teacher also provided discussion materials related to subject matter or difficulties in online learning. Students who had participated in discussion activities and responded or gave solutions to the problem that is being discussed, in the opinion of the teacher can also be said to have responsibility. In the discussion forum, it was clear that the interaction between teachers and students or between students could occur without time and space limitations. This was not the case with offline learning.

To make the students responsible for the online learning activities, teacher gave various tricks. One of them was awards and warnings to students and parents. For the students who had followed online learning well, teacher gave praise and better grades. Otherwise, for the students who hadn't not participated well in online learning for no apparent reason, did not carry out assignments on time, and did not even participate in discussion forums, the teacher gave warnings to students. The teacher also followed up these warnings and communicated with the parents by telephone and WhatsApp.

\subsection{Communication between Parents, Teachers, and Children}

Ki Hajar Dewantara quoted Kemdikbud (2017) as saying that the success of education was very determined by the family, considering in the family the foundation was built so that the family could be referred as an education center [6]. Therefore, between parents and schools should be able to be partners to equally achieve educational goals.

Students of course needed a model that can be used as an ideal example. teacher at the school was be seen as a model of child behavior. In offline learning of course this wouldn't be constrained. But during the covid-19 pandemic today, offline learning was a rare thing. When school buildings or campuses became deserted from learning activities, then actually they learnt the activity beajar activity was happening in cyberspace. Online learning was ultimately not just an alternative, but as a necessity. In these circumstances, students still had to get the right example figure and model to emulate. Errors in providing examples or models caused more serious problems.

Parents in this case should be able to be a model of behaving for their children. With online learning, the child was often at home with his or her parents. It meant that parents should be able to communicate and interacted in a very close intensity. Purandina (2020) states that parents should be able to act as filters that help children filter out negative influences or having a bad impact on their development [7]. Parents had to be abel in acting as a teacher for children with various learning resources close to their daily environment. Parents also did the act act as catalysts that be able to explore and optimized the potential children have.

The importance of communication between teachers and parents was certainly very related to various learning difficulties experienced by the child. Children often express their learning difficulties to parents. 32 respondents (48\%) stated that they conveyed online learning difficulties to their parents. 10 respondents $(15 \%)$ to the brothers, 18 respondents $(27 \%)$ complaints to friends, and only 6 respondents (10\%) complaints about online learning difficulties to teachers. The role of families in accommodating complaints about online learning difficulties is still huge $(63 \%)$. 
Table 8. Communication for submitting complaints and difficulties in online learning.

\begin{tabular}{lcc}
\hline \multicolumn{1}{c}{ Kinds of activities } & $\begin{array}{c}\text { Number of } \\
\text { respondent }\end{array}$ & Percentage \\
\hline Convey learning difficulties to parents & 32 persons & 48,48 \\
Convey learning difficulties to brother or sister & 10 persons & 15,16 \\
Convey learning difficulties to friends & 18 persons & 27,27 \\
Convey learning difficulties to teachers & 6 persons & 9,09 \\
\hline
\end{tabular}

It indicated that the intensive communication between parents and teachers should be happened. So, parents could understood every complaint from the children. On the contrary, complaints submitted by the child to the teacher can be known by the parents. If parents and teachers had already known and understood about the difficulties of learning online, then they could find the best solution for the problems.

Not only in communicating about the child's learning difficulties, parents were expected to supervise and accompany their children's online learning activities. In conducting supervision and mentoring of their children, parents could asked for the opinion of teachers Independent and responsible characters could also grow as expected.

To further strengthen the interaction between the child and the parent, it should be created at home a variety of shared activities involving parents and children. Positive activities conducted at home together form a good emotional bond between the child and the parents. A chemistry that would appear during the activity together, fostering love that later became a habit (habbit) [8]. This concept was actually very good applied in the family environment by getting used to positive character values in each joint activity [9].

\section{Conclusion}

Learning activities during the Covid-19 pandemic should still be carried out with the aim of forming a character that was in accordance with the expectations of masayarakat, religion, nation and country. Self-sustaining values and responsibilities were certainly one of the main characters that must be formed in students. Online learning on the one hand was an alternative to choose from, although on the other hand we had to be prepared to face online learning as a necessity. The most important thing was that the spirit of learning had tobe main turned on in every person, whether teachers, parents, society, especially students.

Any obstacles faced both technically and substantively should be concern to all parties. With the involvement of various parties such as teachers, families, communities, various government and private agencies, then we would feel a great optimism to be able to overcome various problems that arise. The technology used to manage online classes was just a tool. Meanwhile, teachers, students, parents, and the community were the users who would determine which direction education would be brought on the face of the earth. Online learning did require the presence of technology, but the involvement of parents, families, and teachers as well as harmonious communication between these parties was a key that could not be replaced with an application as sophisticated as any. 


\section{References}

[1] Depdiknas. 2003. Sistem Pendidikan Nasional. Jakarta: Depdiknas.

[2] Lilawati, Agustin. 2020. Peran Orang Tua dalam Mendukung Kegiatan Pembelajaran di Rumah pada Masa Pandemi. JPAUD, 2020; 5(1), 549-558.

[3] Lickona, Thomas. 2012. Educating for Character, Mendidik Untuk Membentuk Karakter. Jakarta: Bumi Aksara.

[4] Adisel Adisel, Ahmad Gawdy Prananosa. 2020. Penggunaan Teknologi Informasi dan Komunikasi dalam Sistem Manajemen Pembelajaran pada Masa Pandemi Covid 19. JAEM. 3(1), 1-10

[5] Purandina, I Putu Yoga and Winaya, I Made Astra. 2020. Pendidikan Karakter di Lingkungan Keluarga Selama Pembelajaran Jarak Jauh pada Masa Pandemi COVID-19. Cetta: JIP. 2020; 3(2), 270-290.

[6] Kemdikbud RI. 2017. Peraturan Menteri Pendidikan dan Kebudayaan RI Nomor 30 tahun 2017 Tentang Pelibatan Keluarga pada Penyelenggaraan Pendidikan. Jakarta: Kemdikbud.

[7] Anggito, Albi \& Setiawan, Johan. Metode Penelitian Kualitif. 2018. https://jejakpublisher. com/product/metode-penelitian-kualitatif/. Access Senin, 24 August 2020, 14.32 WIB)

[8] Ratminingsih, N.M. 2019. Pengajaran Karakter dan Cinta. Singaraja. Mahima Institute Indonesia.

[9] Komalasari, K. dan Saripudin, D. 2017. Pendidikan Karakter: Konsep dan Aplikasi Living Values Education. Bandung: PT. Refika Aditama. 